\title{
CHEMICAL CONTROL OF ASIAN SOYBEAN RUST AS A FUNCTION OF CULTIVAR, ROW SPACING AND SPRAY BAR SUPPORT SYSTEMS
}

\author{
Laercio L. Hoffmann ${ }^{*}$, Rafael Roehrig ${ }^{2}$, Walter Boller², Carlos A. Forcelini ${ }^{2}$
}

${ }^{1 *}$ Corresponding author. Programa de Pós-Graduação em Agronomia - Universidade de Passo Fundo/ Passo Fundo - RS, Brasil.

E-mail: laercio.hoffmann@syngenta.com | ORCID ID: https://orcid.org/0000-0001-5056-0477

KEYWORDS
Plant arrangement,
Genetic resistance,
Phakopsora
pachyrhizi.

\begin{abstract}
Product deposition and foliar surface cover are highly impacting factors on the efficiency of foliar fungicides applied to soybean cultivars, due to their low mobility, with side effects on Asian soybean rust (ASR) control. Spray bar support systems, such as the air curtain $\left(\operatorname{Vortex}^{\circledR}\right)$ and the use of nozzles along the bar $\left(\right.$ Dropleg $\left.{ }^{\circledR}\right)$, stand out as an alternative to obtain a better distribution of fungicide throughout the plant. In this study, two spray bar support systems $\left(\right.$ Vortex $^{\circledR}$ and Dropleg ${ }^{\circledR}$ ) were, therefore, evaluated and compared with the conventional spraying method based on the biological efficacy in ASR control. In order to do this, two harvests, with three spacing between rows and two cultivars were employed. Vortex ${ }^{\circledR}$ and Dropleg ${ }^{\circledR}$ spray bar support mechanisms do not effectively contribute to the optimization of Asian soybean rust control or to the grain crop yield, regardless of cultivar and row spacing. Decreasing the row spacing did not influence the level of control of Asian soybean rust, as the highest grain yield was obtained with the smallest spacing. The cultivar with genetic resistance to Asian rust showed lower levels of this disease, thus, greater control against the use of fungicides.
\end{abstract}

\section{INTRODUCTION}

The Phakopsora pachyrhizi and Glycine max pathosystem stands out as one of the most important limiting factor of oilseed productivity, due to the occurrence of the fungus in all countries where soybeans are grown, as well as the potential damage, ranging from 10 to $90 \%$ (Reis et al., 2012, Dalla Lana et al., 2015), the cultivar and the intensity of Asian rust (ASR) (Danelli et al., 2015). As a result, these losses, estimated at 21 billion US dollars, between 2002 and 2013, directly and indirect impacting the Brazilian economy (Godoy et al., 2016).

There are several strategies to control ASR. The restriction of soybean cultivation at certain periods of the year, the elimination of volunteer plants and intermediate hosts, sowing at the beginning of the recommended season and the use of early-cycle cultivars (Godoy et al., 2016; Almeida et al., 2017), combined with changes in cropping practices and plant arrangement (Holtz et al., 2014), varietal resistance (Melo et al., 2015) and fungicide application (Godoy et al., 2016) are integrated measures for disease management (Godoy et al., 2016; Langenbach et al., 2016).

The arrangement of plants, regarding row spacing, impacts on the severity of the ASR and also on the distribution of the fungicide during application. The adoption of wider crop row spacing results in a lower ASR severity, allowing a better distribution of the fungicide during the application and making the management of the disease easier (Holtz et al., 2014). From an epidemiological perspective, low distance of the earlier rows favors disease development as it may generate bad circulation of air, increase in relative humidity and prolongation of leaf surface wetting (Reis et al., 2012).

The use of ASR genetic resistant cultivars is one of the most effective long-term, convenient and cost-effective strategies for disease control (Araújo \& Vello, 2010; Melo et al., 2015). It is based on modifications in the fungus reproductive capacity, particularly regarding sporulation, which affects the progress of the disease due to the reduction of produced spores (Godoy et al., 2016).

From numerous strategies for dealing with ASR, the application of fungicides is a widely used one. In most cases, the uniformity in distribution of the product, provided by the terrestrial and aerial applications, along the soybean canopy, is low (Cunha et al., 2014, Silva et al., 2014). As this is one of the main causes of low efficiency in disease control, strategies that increase the deposition of spray droplets in this canopy layer are necessary (Cunha et al., 2011; Nascimento et al, 2013). Although the main fungicides used in the management of ARS are systemic, they have a loco-systemic action, being transported at small

${ }^{2}$ Programa de Pós-Graduação em Agronomia - Universidade de Passo Fundo/ Passo Fundo - RS, Brasil.

Received in: 6-12-2018

Accepted in: 6-6-2019 
distances from the point of deposition. Adequate distribution throughout the plant, as well as adequate foliar cover are, therefore, required (Reis et al., 2010; Cunha et al., 2014).

The soybean crop receives the highest number of fungicide sprays at reproductive stages, when the plant shows the greatest leaf development. During this period, the leaves of the upper strata constitute a physical barrier against the deposition of fungicide droplets inside the canopy, which makes spraying with conventional bars inefficient. Strategies that increase the deposition, mainly in the lower part of the crop are, therefore required (Cunha et al., 2011; Cunha et al., 2014; Cunha et al., 2016; Moura et al., 2017; Weber et al., 2017). These obstacles can be partially overcome with the use of spray bar support equipment.

Some spraying strategies are able to improve the fungicides deposition, especially on the bottom part of the plant, where the ASR progress starts. Furthermore, some systems to aid the spray bar, such as the $\operatorname{Vortex}^{\circledR}$ and the Dropleg $^{\circledR}$, were developed. The Vortex ${ }^{\circledR}$ system consists of a turbine driven by a hydraulic engine of variable rotation, located in the center of the bar. It produces a volume of air, which is distributed along the spray bar by an inflated duct toward the canopy of the plants through juxtaposed orifices (Bonadio et al., 2015).

The Dropleg ${ }^{\circledR}$ system comprises a nozzle, similar to an inverted walking stick, whose end has two inserted spray tips that penetrate the canopy of the culture and their jets are directed from the bottom up to reach different parts in the interior of the plants canopy. There are two jets applied in this system of bar support: the first one through the spray tips along the spray bar and the second, coming from the inside of the plant canopy (Rüegg \& Total, 2013).

The objective of this work was, therefore, to determine if the Vortex $^{\circledR}$ and Dropleg ${ }^{\circledR}$ spray bar support mechanisms improve ASR control, by comparing them to the conventional application method with different soybean row spacing and cultivars, of different ASR genetic resistance levels.

\section{MATERIAL AND METHODS}

The experiments were conducted on a soybean monoculture area with residues of black oat crop. The management of weeds, pests, fertilization and other cultivation practices occurred according to the crop's technical indications. During the V7 stage (Fehr et al., 1971), the fungicide difenoconazole + propiconazole $(37.5$ $\mathrm{g}+37.5 \mathrm{~g} \mathrm{ha}^{-1}$ ) was applied using a conventional bar equipped with flat jet tips LU 11002 , with $150 \mathrm{~L} \mathrm{ha}^{-1}$ mixture volume and fine droplet spectrum (ASABE, 2009), throughout the experimental area, except for the controls.

Two soybean cultivars, SYN $1363 \mathrm{RR}$ and SYN $1365 \mathrm{RR}$, were used. The SYN $1363 \mathrm{RR}$ cultivar is characterized by its susceptibility to ASR, 6.3 maturation group, medium cycle, indeterminate growth habit and erect posture. The SYN 1365 RR cultivar, on the other hand, is characterized as ASR-resistant, 6.5 maturation group, medium cycle, indeterminate growth habit and erect posture. Both cultivars were established with $30( \pm 5 \%)$ plants $\mathrm{m}^{-2}$ density and each one consisted of an independent assay.

The experimental design was taken in randomized blocks of subdivided portions, with three replicates. The spacing was allocated in the main plot and the spray bar support systems in the other two. The main plots consisted of the following spacing between the rows: $0.17 \mathrm{~m} ; 0.34 \mathrm{~m}$ and $0.51 \mathrm{~m}$. The plots dimensions were: $3.0 \mathrm{~m}$ wide by 7.0 $\mathrm{m}$ long ( 18 rows of $0.17 \mathrm{~m}, 9$ rows of $0.34 \mathrm{~m}$ and 7 rows of $0.51 \mathrm{~m})$. The experiment was repeated and separately evaluated with two harvests. In the first year, 2013/2014 harvest, sowing was carried out on December 20th of 2013 while in 2014/2015 harvest it occurred on December 5 of 2014. Evaluated spray bar support systems were the Vortex $^{\circledR}$ air curtain, the Dropleg ${ }^{\circledR}$ nozzle and the conventional system (Table 1).

TABLE 1. Spray bar support systems utilized for fungicide application, spray tips, mixture volume, operation speed and pressure. FAMV/UPF, Passo Fundo - RS, 2018.

\begin{tabular}{|c|c|c|}
\hline & Treatments & Description \\
\hline 1 & Control & No fungicide application \\
\hline 2 & Conventional & $\begin{array}{l}130 \mathrm{~L} \mathrm{ha}^{-1} \text { volume, LU* } 12002 \text { flat jet tips, spaced } 0.50 \mathrm{~m} \text { in the top of the bar, fine droplets, and } \\
0.65 \mathrm{~L} \mathrm{~min}^{-1} \text { flow }\end{array}$ \\
\hline 3 & Vortex $^{\circledR}$ & $\begin{array}{l}130 \mathrm{~L} \mathrm{ha}^{-1} \text { volume, LU* } 12002 \text { flat jet tips }\left(0.65 \mathrm{~L} \cdot \mathrm{min}^{-1} \text { flow }\right) \text {; fine droplets, } 3.3 \text { to } 4.2 \mathrm{~m} \mathrm{~s}^{-1} \text { wind } \\
\text { speed in the air curtain** perpendicular to the ground. }\end{array}$ \\
\hline 4 & Dropleg $^{\circledR}$ & $\begin{array}{l}65 \mathrm{~L} \mathrm{ha}^{-1} \text { volume in the upper part, LU } 12001 \text { flat jet tips, } 0.32 \mathrm{~L} \mathrm{~min}^{-1} \text { in the upper part of the } \\
\text { bar, fine droplets combined with two empty conical jet tips } 8001 \text {, at the end of the flexible stem } \\
\left(0.32 \mathrm{~L} \mathrm{~min}^{-1}\right) \text {, fine droplet. }\end{array}$ \\
\hline
\end{tabular}

*LU tips: universal use tip; manufacturer: Lechler; $1.7 \mathrm{~m} \mathrm{~s}^{-1}$ displacement speed; $200 \mathrm{kPa}$ pressure.

** Wind speed measured $0.5 \mathrm{~m}$ from the air outlet. Fine droplets: 106 to $235 \mu \mathrm{m}$ (ASABE, 2009).

The Dropleg ${ }^{\circledR}$ spray bar support system was made of $0.90 \mathrm{~m}$ long nozzles (flexible tubes) with a curl, similar to a walking stick at the lower end, attached to the spray bar by the upper end, by means of metal supports, $0.50 \mathrm{~m}$ spaced and positioned between the rows of the crop oscillating longitudinally and laterally. At the lower ends of these nozzles, the "multijet" nozzles are directed upwards and are associated with an anti-dripping diaphragm valve to prevent the mixture flow. Next to the upper end of the nozzle there was a flexible hose to be inserted into the nozzle holder of the spray bar. In this spray bar support system, therefore, the droplets are sprayed from the bottom upwards, with conventional spray tips (spacing $0.50 \mathrm{~m}$ ) maintained in the bars for top-down applications.

Sprayings were made by the Jacto Falcon AM 14 equipment, with a Vortex ${ }^{\circledR}$ bar support system. Applications 
took place during the reproductive stage of the crop, in (R2 $=$ Fehr et al., 1971) and R2 + 18 day, employing the fungicide azoxystrobin + benzovindiflupyr $(60 \mathrm{~g}+30$ $\left.\mathrm{g} \mathrm{ha}^{-1}\right)$. The third application, R2 +30 days, used the fungicide azoxystrobin + cyproconazole $\left(60 \mathrm{~g}+24 \mathrm{~g} \mathrm{ha}^{-1}\right)$. $600 \mathrm{~mL} \mathrm{ha}^{-1}$ of Nimbus ${ }^{\circledR}$ adjuvant $(42.8 \%$ paraffinic mineral oil) were also added to the mixture.

During the intervals between treatment changes, pressure stabilization and standardization of the jets in an adjacent area of the experiment, were expected. The applications were executed at the end of the afternoon, with temperatures below $30^{\circ} \mathrm{C}$ and relative humidity above $60 \%$, and were monitored by a digital thermo-hygro-anemometer.

The ASR severity was evaluated from the diagrammatic scale developed by Godoy et al. (2016) in five plants of each plot from stage R2, which consisted of six evaluations in total. The evaluations were, afterward, integrated as an area below the ASR progress curve (ABASRC), using the equation: $\mathrm{ABASRC}=\sum\left[\left(\left(\mathrm{y}_{1}+\mathrm{y}_{2}\right) / 2\right)\right.$ $\left.\mathrm{x}\left(\mathrm{t}_{2}-\mathrm{t}_{1}\right)\right]$, where: $\mathrm{y}_{1}$ and $\mathrm{y}_{2}$ are, respectively, the leaf severity at the dates of two consecutive severity readings $\left(t_{1}\right.$ and $\left.t_{2}\right)$. We calculated the relative area below the ASR progress curve (RABASRC) by dividing the ABASRC by the time between the first and the last evaluation in each treatment. For the evaluation of defoliation, the scale of Hirano et al. (2010) was used from the moment that the control without application of fungicide reached a defoliation level near $90 \%$.

At the end of the crop cycle, the central areas of plots were mechanically harvested (Wintersteiger plot harvester, A-4910). Grains were benefitted, had their moisture content and weight determined, and corrected to $13 \%$ moisture for estimating the grain yield $\left(\mathrm{kg} \mathrm{ha}^{-1}\right)$ and the mass of a thousand grains $(\mathrm{g})$.

The results obtained for severity, RABASRC, defoliation, grain yield and mass of a thousand grains were submitted to a variance analysis. The means were also compared by the Scott-Knott test $(p \leq 0.05)$ in the SASM-AGRI ${ }^{\circledR}$ program.

\section{RESULTS AND DISCUSSION}

In the $2013 / 2014$ and $2014 / 2015$ seasons, the environmental conditions allowed the crop to fulfill its productive potential, and were favorable to ASR development. Leaf spot and powdery mildew occurrences in severities were below 3\% and, therefore, were disregarded. In March of 2014/2015 harvest, there was a reduction in rainfall, however, the productive potential was not affected.

For both crops and cultivars (SYN 1363 RR, SYN $1365 \mathrm{RR}$ ), the spraying methods and spacing did not promote significant interactions between the severity of the ASR, RABASRC, defoliation, grain yield and thousand-grain mass, indicating that these factors were independent. In the 2013/2014 season of the SYN 1363 RR cultivar, the ASR severity in the plots with no fungicide application reached $77 \%$ and in the 2014/2015 harvest it was of 55.6\%, as a result from the late implantation of crop and early start of the epidemic.

The reduction in row spacing did not affect the ARS severity evolution. The disease reached approximately $25 \%$ in the 2013/2014 harvest in the susceptible cultivar (Table 2 ) and for both spacing, providing control levels of around $90 \%$. In the ASR-resistant cultivar (Table 3), the severity of the disease was close to $10 \%$ and disease control was higher than $90 \%$. Defoliation levels disclosed similar results from the high degree of disease control (regardless of the spacing between the rows), reaching $27 \%$ for the susceptible cultivar and $34 \%$ for the resistant cultivar (Table 2 and Table 3).

In 2013/2014 harvest, the conventional spraying system and the Vortex ${ }^{\circledR}$ bar support mechanism provided the best levels of ASR control in both cultivars. As a result, RABASRC, disease severity and defoliation (as it is influenced by the other variables) were reduced by approximately $59 \%, 64 \%$ and $56 \%$, respectively when compared to the Dropleg ${ }^{\circledR}$ method, based on the susceptible cultivar. Meanwhile, in the ASR-resistant cultivar, these reductions were around $63 \%, 59 \%$ and $43 \%$ in RABASRC, in disease severity and defoliation, respectively (Table 2 and Table 3), in relation to Dropleg ${ }^{\circledR}$.

TABLE 2. Relative area below the Asian soybean rust progress curve (RABASRC), severity of Asian soybean rust (\%) in stage R6 and defoliation (\%) in stage R7, as a function of different spray bar support mechanisms, in fungicide applications and soybean crop row spacing, cultivar SYN 1363 RR, 2013/2014 harvest. Passo Fundo, RS, 2018.

\begin{tabular}{|c|c|c|c|c|}
\hline \multirow{2}{*}{ Spraying Method } & \multicolumn{3}{|c|}{ Row spacing } & \multirow{2}{*}{ Mean } \\
\hline & $0.17 \mathrm{~m}$ & $0.34 \mathrm{~m}$ & $0.51 \mathrm{~m}$ & \\
\hline & \multicolumn{4}{|c|}{ RABASRC } \\
\hline Control & 29.3 & 29.5 & 31.6 & $30.1 \mathrm{a}$ \\
\hline Conventional & 2.4 & 1.6 & 2.1 & $2.0 \mathrm{c}$ \\
\hline Dropleg $^{\circledR}$ & 5.7 & 5.2 & 5.5 & $5.5 \mathrm{~b}$ \\
\hline Vortex $^{\mathbb{B}}$ & 2.9 & 2.1 & 1.5 & $2.2 \mathrm{c}$ \\
\hline \multirow[t]{2}{*}{ Mean NS } & 10.1 & 9.6 & 10.2 & 10.0 \\
\hline & \multicolumn{4}{|c|}{ Severity* \% } \\
\hline Control & 76.0 & 75.0 & 80.0 & $77.0 \mathrm{a}$ \\
\hline Conventional & 5.7 & 3.0 & 5.7 & $4.8 \mathrm{c}$ \\
\hline Dropleg $^{\circledR}$ & 11.3 & 11.0 & 13.0 & $11.8 \mathrm{~b}$ \\
\hline Vortex $^{\circledR}$ & 6.7 & 4.3 & 4.0 & $5.0 \mathrm{c}$ \\
\hline \multirow[t]{2}{*}{ Mean $^{\text {NS }}$} & 24.9 & 23.3 & 25.7 & 24.6 \\
\hline & \multicolumn{4}{|c|}{ Defoliation \% } \\
\hline Control & 93.3 & 92.7 & 93.3 & $93.1 \mathrm{a}$ \\
\hline Conventional & 10.7 & 10.7 & 12.3 & $11.2 \mathrm{c}$ \\
\hline Dropleg $^{\circledR}$ & 16.0 & 21.7 & 21.7 & $19.8 \mathrm{~b}$ \\
\hline Vortex $^{\circledR}$ & 14.0 & 13.0 & 10.7 & $12.6 \mathrm{c}$ \\
\hline Mean $^{\text {NS }}$ & 33.5 & 34.5 & 34.5 & 34.2 \\
\hline
\end{tabular}

*Data transformed into $\sqrt{\mathrm{x}}$ for statistical analysis. Means followed by the same lowercase letter in the column did not differ by Scott-Knott's test (p $<0.05)$. NS: not significant.

C.V. RABASRC: (a) 11.7\%, (b) 6.5\%; C.V. severity: (a) $11.9 \%$, (b) 6.8\%; C.V. defoliation: (a) $6.7 \%$, (b) $8.9 \%$. 
In 2013/2014 harvest, due to better ASR control, both the conventional and the Vortex ${ }^{\circledR}$ spray methods reduced the damage by approximately $6 \%\left(242 \mathrm{~kg} \mathrm{ha}^{-1}\right)$ in the susceptible cultivar. The mass of a thousand grain variable was also negatively affected by approximately $4.4 \%$ due to the use of Dropleg ${ }^{\circledR}$, in relation to the other spraying methods (Table 4). The grain yield was influenced by the proximity between the rows, which provided a $14 \%$ increase in yield, from $3,422 \mathrm{~kg} \mathrm{ha}^{-1}$, with $0.51 \mathrm{~m}$, to 3,897 $\mathrm{kg} \mathrm{ha}^{-1}$, with $0.17 \mathrm{~m}$ (Table 4). In the 2013/2014 harvest and for the ASR-resistant soybean cultivar SYN 1365, the grain yield and the thousand-grain mass were similar, regardless of the spraying method employed, as well as the spacing between the cultivation rows (Table 5).

TABLE 3. Relative area below the Asian soybean rust progress curve (RABASRC), severity of Asian soybean rust (\%) in stage R6 and defoliation (\%) in stage R7, as a function of different spray bar support mechanisms, in fungicide applications and soybean crop row spacing, cultivar SYN 1365 RR, 2013/2014 harvest. Passo Fundo, RS, 2018.

\begin{tabular}{|c|c|c|c|c|}
\hline \multirow{2}{*}{ Spraying Method } & \multicolumn{3}{|c|}{ Row spacing } & \multirow{2}{*}{ Mean } \\
\hline & $0.17 \mathrm{~m}$ & $0.34 \mathrm{~m}$ & $0.51 \mathrm{~m}$ & \\
\hline & \multicolumn{4}{|c|}{ RABASRC } \\
\hline Control & 14.1 & 13.5 & 14.3 & $14.0 \mathrm{a}$ \\
\hline Conventional & 0.7 & 0.6 & 0.9 & $0.7 \mathrm{c}$ \\
\hline Dropleg $^{\circledR}$ & 2.2 & 1.1 & 1.8 & $1.7 \mathrm{~b}$ \\
\hline Vortex $^{\mathbb{R}}$ & 0.9 & 0.6 & 0.7 & $0.7 \mathrm{c}$ \\
\hline \multirow[t]{2}{*}{ Mean $^{\text {NS }}$} & 4.5 & 4.0 & 4.4 & 4.3 \\
\hline & \multicolumn{4}{|c|}{ Severity* (\%) } \\
\hline Control & 34.3 & 34.3 & 36.0 & $34.9 \mathrm{a}$ \\
\hline Conventional & 1.3 & 1.3 & 2.7 & $1.8 \mathrm{c}$ \\
\hline Dropleg $^{\circledR}$ & 5.3 & 2.3 & 4.0 & $3.9 \mathrm{~b}$ \\
\hline Vortex $^{\circledR}$ & 1.0 & 1.3 & 2.0 & $1.4 \mathrm{c}$ \\
\hline \multirow[t]{2}{*}{ Mean $^{\text {NS }}$} & 10.5 & 9.8 & 11.2 & 10.5 \\
\hline & \multicolumn{4}{|c|}{ Defoliation $(\%)$} \\
\hline Control & 88.3 & 89.3 & 86.7 & $88.1 \mathrm{a}$ \\
\hline Conventional & 5.3 & 4.7 & 4.7 & $4.9 \mathrm{c}$ \\
\hline Dropleg $^{\circledR}$ & 10.0 & 12.0 & 11.3 & $11.1 \mathrm{~b}$ \\
\hline Vortex $^{\circledR}$ & 5.3 & 5.7 & 4.3 & $5.1 \mathrm{c}$ \\
\hline Mean NS & 27.3 & 27.9 & 26.8 & 27.3 \\
\hline
\end{tabular}

* Data transformed into $\sqrt{\mathrm{x}}$ for statistical analysis. Means followed by the same uppercase letter in the row and lowercase letter in the column do not differ by Scott-Knott's test $(\mathrm{p}<0.05)$. N.S.: not significant.

C.V. RABASRC: (a) 11.8\%, (b) 10.3\%; C.V. severity: (a) 20.1\%, (b) 18.3\%; C.V. defoliation: (a) 15.0 \%, (b): $12.0 \%$.

TABLE 4. Grain yield ( $\left.\mathrm{kg} \mathrm{ha}^{-1}\right)$ and thousand-grain mass $(\mathrm{g})$ as a function of different spacing and spray bar support mechanisms, in fungicide applications in soybean crop, cultivar SYN 1363 RR, 2013/2014 harvest. Passo Fundo, RS, 2018.

\begin{tabular}{|c|c|c|c|c|}
\hline \multirow{2}{*}{ Spraying Method } & \multicolumn{3}{|c|}{ Row spacing } & \multirow{2}{*}{ Mean } \\
\hline & $0.17 \mathrm{~m}$ & $0.34 \mathrm{~m}$ & $0.51 \mathrm{~m}$ & \\
\hline & \multicolumn{4}{|c|}{ Yield $\left(\mathrm{kg} \mathrm{ha}^{-1}\right)$} \\
\hline Control & 2040 & 1986 & 1614 & $1880 \mathrm{c}$ \\
\hline Conventional & 4674 & 4566 & 4050 & $4430 \mathrm{a}$ \\
\hline Dropleg $^{\mathbb{R}}$ & 4332 & 4266 & 3966 & $4188 \mathrm{~b}$ \\
\hline Vortex $^{\circledR}$ & 4542 & 4518 & 4056 & $4372 \mathrm{a}$ \\
\hline \multirow[t]{2}{*}{ Mean } & $3897 \mathrm{~A}$ & $3834 \mathrm{~A}$ & $3422 \mathrm{~B}$ & 3718 \\
\hline & \multicolumn{4}{|c|}{ Thousand-grain mass (g) } \\
\hline Control & 92.1 & 90.6 & 90.7 & $91.1 \mathrm{c}$ \\
\hline Conventional & 163.8 & 163.2 & 159.2 & $162.1 \mathrm{a}$ \\
\hline Dropleg ${ }^{\circledR}$ & 157.3 & 155.0 & 155.7 & $156.0 \mathrm{~b}$ \\
\hline Vortex $^{\mathbb{R}}$ & 163.0 & 161.6 & 165.0 & $163.2 \mathrm{a}$ \\
\hline Mean $^{\text {NS }}$ & 144.0 & 142.6 & 142.7 & 143.1 \\
\hline
\end{tabular}

Means followed by the same uppercase letter in the row and lowercase letter in the column do not differ by Scott-Knott's test ( $<<0.05$ ). N.S.: not significant.

C.V. yield: (a) $8.8 \%$, (b) $9.5 \%$; C.V. thousand-grain mass: (a) $1.8 \%$, (b) $2.7 \%$. 
TABLE 5. Grain yield $\left(\mathrm{kg} \mathrm{ha}^{-1}\right)$ and thousand-grain mass $(\mathrm{g})$ as a function of different spacing and spray bar support mechanisms, in fungicide applications in soybean crop, cultivar SYN 1365 RR, 2013/2014 harvest. Passo Fundo, RS, 2018.

\begin{tabular}{|c|c|c|c|c|}
\hline \multirow{2}{*}{ Spraying Method } & \multicolumn{3}{|c|}{ Row spacing } & \multirow{2}{*}{ Mean } \\
\hline & $0.17 \mathrm{~m}$ & $0.34 \mathrm{~m}$ & $0.51 \mathrm{~m}$ & \\
\hline & \multicolumn{4}{|c|}{ Yield $\left(\mathrm{kg} \mathrm{ha}^{-1}\right)$} \\
\hline Control & 3220 & 3030 & 3166 & $3139 \mathrm{~b}$ \\
\hline Conventional & 4310 & 4122 & 4040 & $4157 \mathrm{a}$ \\
\hline Dropleg $^{\circledR}$ & 4270 & 4130 & 4168 & $4189 \mathrm{a}$ \\
\hline Vortex $^{\circledR}$ & 4314 & 4248 & 4192 & $4251 \mathrm{a}$ \\
\hline \multirow[t]{2}{*}{ Mean NS } & 4029 & 3883 & 3892 & 3934 \\
\hline & \multicolumn{4}{|c|}{ Thousand-grain mass (g) } \\
\hline Control & 134.8 & 136.5 & 129.6 & $133.6 \mathrm{~b}$ \\
\hline Conventional & 176.1 & 175.3 & 169.6 & $173.7 \mathrm{a}$ \\
\hline Vortex $^{\circledR}$ & 168.4 & 178.6 & 171.0 & $172.7 \mathrm{a}$ \\
\hline Dropleg $^{\circledR}$ & 166.8 & 170.0 & 168.2 & $168.3 \mathrm{a}$ \\
\hline Mean NS $^{\text {NS }}$ & 161.5 & 165.1 & 159.6 & 162.1 \\
\hline
\end{tabular}

Means followed by the same uppercase letter in the column and lowercase letter in the row do not differ by Scott-Knott's test ( $\mathrm{p}<0.05)$. N.S.: not significant.

C.V. yield: (a) 1.8\%, (b): 2.7\%; C.V. thousand-grain mass: (a) $2.4 \%$, (b) $3.1 \%$.

There was no influence of row spacing on ASR evolution, in the 2014/2015 harvest, in which levels close to $22 \%$ were reached in the susceptible cultivar (SYN 1363 RR). Meanwhile, in the resistant cultivar (SYN 1365 RR), this value was of $10 \%$. Moreover, the control of the disease was near $85 \%$ and $94 \%$ for these cultivars, respectively, thus, not impacting on the defoliation (Table 6 and Table 7).

The ASR severity disclosed a relation with the spraying method for the susceptible cultivar, where the use of the Dropleg ${ }^{\circledR}$ bar support mechanism indicated a $11 \%$ reduction in disease control, comparatively with the conventional method, with a 2.4 times increase in the ASR severity, thus increasing the RABASRC by 2.0 times. The conventional spraying method, therefore, presented $60 \%$ less defoliation than the Dropleg ${ }^{\circledR}$ system, due to the optimization of the control (Table 6). Furthermore, the resistant cultivar had equivalent ASR and defoliation levels in both spraying methods (Table 7).

TABLE 6. Relative area below the Asian soybean rust progress curve (RABASRC), severity of Asian soybean rust (\%) in stage R6 and defoliation (\%) in stage R7, as a function of different spray bar support mechanisms, in fungicide applications and soybean crop row spacing, cultivar SYN 1363 RR, 2014/2015 harvest. Passo Fundo, RS, 2018.

\begin{tabular}{|c|c|c|c|c|}
\hline \multirow{2}{*}{ Spraying Method } & \multicolumn{3}{|c|}{ Row spacing } & \multirow{2}{*}{ Mean } \\
\hline & $0.17 \mathrm{~m}$ & $0.34 \mathrm{~m}$ & $0.51 \mathrm{~m}$ & \\
\hline & \multicolumn{3}{|c|}{ RABASRC } & \\
\hline Control & 24.3 & 22.8 & 24.9 & $24.3 \mathrm{a}$ \\
\hline Conventional & 2.4 & 1.8 & 1.2 & $2.4 \mathrm{c}$ \\
\hline Dropleg $^{\circledR}$ & 4.8 & 4.4 & 4.5 & $4.8 \mathrm{~b}$ \\
\hline \multirow[t]{2}{*}{ Mean $^{\text {NS }}$} & 10.5 & 9.6 & 10.2 & 10.5 \\
\hline & \multicolumn{3}{|c|}{ Severity (\%) } & \\
\hline Control & 54.7 & 54.3 & 57.7 & $55.6 \mathrm{a}$ \\
\hline Conventional & 5.0 & 3.0 & 2.7 & $3.6 \mathrm{c}$ \\
\hline Dropleg $\left.^{(}\right)$ & 8.0 & 8.0 & 9.7 & $8.6 \mathrm{~b}$ \\
\hline \multirow[t]{2}{*}{ Mean NS } & 22.6 & 21.8 & 23.3 & 22.6 \\
\hline & \multicolumn{3}{|c|}{ Defoliation (\%) } & \\
\hline Control & 86.3 & 87.8 & 84.8 & $86.3 \mathrm{a}$ \\
\hline Conventional & 6.5 & 6.0 & 5.8 & $6.1 \mathrm{c}$ \\
\hline Dropleg $^{\circledR}$ & 16.0 & 14.0 & 14.5 & $14.8 \mathrm{~b}$ \\
\hline Mean NS & 36.3 & 35.9 & 35.0 & 35.7 \\
\hline
\end{tabular}

*Data transformed into $\sqrt{\mathrm{x}}$ for statistical analysis. Means followed by the same uppercase letter in the row and lowercase letter in the column do not differ by Scott-Knott's test $(\mathrm{p}<0.05)$. N.S.: not significant.

C.V. RABASRC: (a): 12.2\%, (b): 10.0\%; C.V. severity (a): $8.6 \%$, (b): 5.4\%; C.V. defoliation: (a): 13.2\%, (b): $15.8 \%$. 
TABLE 7. Relative area below the Asian soybean rust progress curve (RABASRC), severity of Asian soybean rust (\%) in stage R6 and defoliation (\%) in stage R7, as a function of different spray bar support mechanisms, in fungicide applications and soybean crop row spacing, cultivar SYN 1365 RR, 2014/2015 harvest. Passo Fundo, RS, 2018.

\begin{tabular}{|c|c|c|c|c|}
\hline \multirow{2}{*}{ Spraying Method } & \multicolumn{3}{|c|}{ Row spacing } & \multirow{2}{*}{ Mean } \\
\hline & $0.17 \mathrm{~m}$ & $0.34 \mathrm{~m}$ & $0.51 \mathrm{~m}$ & \\
\hline & \multicolumn{4}{|c|}{ RABASRC } \\
\hline Control & 11.9 & 12.2 & 12.6 & $12.2 \mathrm{a}$ \\
\hline Conventional & 0.9 & 0.6 & 0.7 & $0.7 \mathrm{c}$ \\
\hline Dropleg $^{\circledR}$ & 2.1 & 1.1 & 1.6 & $1.6 \mathrm{~b}$ \\
\hline \multirow[t]{2}{*}{ Mean NS $^{\text {NS }}$} & 12.5 & 11.5 & 12.4 & 4.8 \\
\hline & \multicolumn{4}{|c|}{ Severity* $(\%)$} \\
\hline Control & 25.5 & 28.6 & 30.0 & $28.0 \mathrm{a}$ \\
\hline Conventional & 0.8 & 1.0 & 1.7 & $1.1 \mathrm{~b}$ \\
\hline Dropleg $^{\circledR}$ & 4.9 & 2.3 & 3.9 & $3.7 \mathrm{~b}$ \\
\hline \multirow[t]{2}{*}{ Mean NS $^{\text {NS }}$} & 10.4 & 10.6 & 11.9 & 10.9 \\
\hline & \multicolumn{4}{|c|}{ Defoliation (\%) } \\
\hline Control & 68.8 & 70.0 & 67.5 & $68.8 \mathrm{a}$ \\
\hline Conventional & 5.3 & 4.8 & 6.0 & $5.3 \mathrm{~b}$ \\
\hline Dropleg $^{\mathbb{B}}$ & 5.3 & 8.3 & 6.3 & $6.6 \mathrm{~b}$ \\
\hline Mean NS & 26.4 & 27.7 & 26.6 & 26.9 \\
\hline
\end{tabular}

* Data transformed into $\sqrt{\mathrm{x}}$ for statistical analysis. Means followed by the same uppercase letter in the row and lowercase letter in the column do not differ by Scott-Knott's test $(\mathrm{p}<0.05)$. N.S.: not significant.

C.V. RABASRC: (a) $15.7 \%$, (b) 14.6\%; C.V. severity: (a) 10.7\%, (b): 12.7\%; C.V. defoliation: (a) $12.0 \%$, (b): $16.0 \%$.

Although the grain yield was not affected in the $2014 / 2015$ harvest by the spraying methods for both cultivars, the thousand-grain mass increased by nearly $5 \%$ for the susceptible cultivar and about $2 \%$ for the resistant cultivar, from the use of the conventional method in relation to Dropleg ${ }^{\circledR}$ (Table 8 and Table 9). Reduction of row spacing increased grain yield by approximately $6.5 \%$ and $8.6 \%$ for the susceptible cultivar (SYN $1363 \mathrm{RR}$ ) and for the resistant cultivar (SYN 1365 RR), respectively, by observing the $0.17 \mathrm{~m}$ spacing between rows in relation to the other ones (Table 8 and Table 9).

TABLE 8. Grain yield $\left(\mathrm{kg} \mathrm{ha}^{-1}\right)$ and thousand-grain mass as a function of different row spacing and fungicide application methods in soybean crop, cultivar SYN 1363 RR, 2014/2015 harvest. Passo Fundo, RS, 2018.

\begin{tabular}{|c|c|c|c|c|}
\hline \multirow{2}{*}{ Spraying Method } & \multicolumn{3}{|c|}{ Row spacing } & \multirow{2}{*}{ Mean } \\
\hline & $0.17 \mathrm{~m}$ & $0.34 \mathrm{~m}$ & $0.51 \mathrm{~m}$ & \\
\hline & \multicolumn{4}{|c|}{ Grain yield $\left(\mathrm{kg} \mathrm{ha}^{1}\right)$} \\
\hline Control & 2990 & 2769 & 2679 & $2813 \mathrm{~b}$ \\
\hline Conventional & 4391 & 4040 & 4095 & $4175 \mathrm{a}$ \\
\hline Dropleg $^{\circledR}$ & 4098 & 3965 & 3984 & $4016 \mathrm{a}$ \\
\hline \multirow[t]{2}{*}{ Mean } & $3826 \mathrm{~A}$ & $3591 \mathrm{~B}$ & $3586 \mathrm{~B}$ & 3668 \\
\hline & \multicolumn{4}{|c|}{ Thousand-grain mass (g) } \\
\hline Control & 103.5 & 103.5 & 102.8 & $103.3 \mathrm{c}$ \\
\hline Conventional & 141.0 & 140.0 & 144.0 & $141.7 \mathrm{a}$ \\
\hline Dropleg $^{\circledR}$ & 137.0 & 134.5 & 134.8 & $135.4 \mathrm{~b}$ \\
\hline Mean NS & 127.2 & 126.0 & 127.2 & 126.8 \\
\hline
\end{tabular}

Means followed by the same uppercase letter in the column and lowercase letter in the row do not differ by Scott-Knott's test (p<0.05). N.S.: not significant.

C.V. yield: (a) $6.4 \%$, (b) $4.3 \%$; C.V. thousand-grain mass: (a) $2.7 \%$, (b) $2.1 \%$.

TABLE 9. Grain yield $\left(\mathrm{kg} \mathrm{ha}^{-1}\right)$ and thousand-grain mass as a function of different row spacing and fungicide application methods in soybean crop, cultivar SYN 1365 RR, 2014/2015 harvest. Passo Fundo, RS, 2018.

\begin{tabular}{|c|c|c|c|c|}
\hline \multirow{2}{*}{ Spraying Method } & \multicolumn{3}{|c|}{ Row spacing } & \multirow{2}{*}{ Mean } \\
\hline & $0.17 \mathrm{~m}$ & $0.34 \mathrm{~m}$ & $0.51 \mathrm{~m}$ & \\
\hline & \multicolumn{4}{|c|}{ Grain yields $\mathrm{Kg} \mathrm{ha}^{-1}$} \\
\hline Control & 3390 & 3306 & 3228 & $3306 \mathrm{~b}$ \\
\hline Conventional & 4248 & 3828 & 3816 & $3966 \mathrm{a}$ \\
\hline Dropleg $^{\circledR}$ & 4224 & 3792 & 3774 & $3930 \mathrm{a}$ \\
\hline \multirow[t]{2}{*}{ Mean } & $3954 \mathrm{~A}$ & $3642 \mathrm{~B}$ & $3606 \mathrm{~B}$ & 3732 \\
\hline & \multicolumn{4}{|c|}{ Thousand-grain mass (g) } \\
\hline Control & 147.4 & 148.9 & 148.4 & $148.2 \mathrm{c}$ \\
\hline Conventional & 164.2 & 165.3 & 164.2 & $164.6 \mathrm{~b}$ \\
\hline Dropleg $^{\circledR}$ & 166.4 & 167.6 & 168.4 & $167.5 \mathrm{a}$ \\
\hline Mean NS & 159.3 & 160.7 & 160.1 & 160.1 \\
\hline
\end{tabular}

Means followed by the same uppercase letter in the column and lowercase letter in the row do not differ by Scott-Knott's test (p<0.05). N.S.: not significant.

C.V. yield: (a) $4.1 \%$, (b) $4.5 \%$. C.V. thousand-grain mass: (a) $1.6 \%$, (b) $1.5 \%$. 
One of the main reasons for ineffective ASR control is associated with the target coverage deficiency by the application of fungicides, especially at the lower portion of the plant (Cunha et al., 2014; Silva et al., 2014; Cunha et al., 2016; Moura et al., 2017, Weber et al., 2017). The control efficacy becomes, therefore, compromised, as fungicides for ASR management, although systemic, are translocated to small distances from the deposition point (Reis et al., 2010). Consequently, the efficiency of the application is determined by the proper deposition and distribution of the active ingredient on the target.

When analyzing the effect of the air supply through a series of works, Oliveira et al. (2016) indicated that this mechanism of support to the spray bar had no effect on the performance of agrochemicals and the control levels of phytopathogenic fungi. The contrasting and variable effects on the Vortex ${ }^{\circledR}$ system may be associated with the different canopy opening levels, which can be influenced by the plant arrangement (Holtz et al., 2014), depending on the characteristic of the cultivar (Debortoli et al., 2012; Tormen et al., 2012), as well as by the time of the day of spraying, due to the variation of the horizontal angle of soybean leaves throughout the day (Graziano et al., 2017; Moura et al., 2017). Moreover, the spray tip angle, droplet size and speed, adjuvants and mixture volume are factors that also influence droplets' penetration along the canopy of the plant (Cunha et al., 2014, Madureira et al., 2015; Prado et al., 2015; Cunha et al., 2016; Weber et al., 2017, França et al., 2018).

Under open canopy conditions, therefore, the use of the $\operatorname{Vortex}^{\circledR}$ bar support system does not influence the distribution of the applied mixture. In case of a closed canopy with high leaf area index, however, the air supply can increase deposits and leaf coverage throughout the plant. As a result, the ASR control may be improved, providing increased productivity and thousand-grain mass (Christovam et al., 2010; Prado et al., 2010), or may be optimized, increasing mixture deposition into the soybean canopy. Levels of coverage, however, are still insufficient to optimize the ASR control (Baesso et al., 2014).

The utilization of the Dropleg ${ }^{\circledR}$ bar support system aims at the enhancement of mixture accessibility at sites, such as the bottom part of the plant. Still considering that the system operates inside the canopy, a better drift control driven by wind action exists, as well as the possibility of varying the ratio between the amount of mixture sprayed through the Dropleg ${ }^{\circledR}$ system and the conventional spray bar, as both can be adjusted according to the growth of the crop (Roten et al., 2013; Rüegg \& Total, 2013).

In works with bean cultivation in France and Switzerland, the use of the Dropleg ${ }^{\circledR}$ bar support mechanism provided an improvement in the biological efficacy of fungicides from $40 \%$ (conventional spray) to $80 \%$ (using the Dropleg ${ }^{\circledR}$ method (Rüegg \& Total, 2013)) compared to Sclerotinia sp. When targeting ASR, however, the Dropleg ${ }^{\mathbb{R}}$ spray system proved to be inferior to the others from some analyzed variables perspectives. The lower ASR and productivity control may be associated with the adjustment of the mechanism in relation to the soybean canopy, as the flexible stems were $0.9 \mathrm{~m}$ length and the sprayer bar operated between $0.4 \mathrm{~m}$ and $0.5 \mathrm{~m}$ above the plants canopy. As a result, the flexible stem penetrated between $0.4 \mathrm{~m}$ and $0.5 \mathrm{~m}$ inside the canopy, not reaching the bottom.
The yield of the smaller row spacing provided increases, due to better distribution of plants in the area and to the interception of solar radiation, resulting in smaller spacing (the critical leaf area index was obtained earlier). Moreover, this allows the interception of at least $90 \%$ of the photosynthetically active radiation, optimizing the photosynthesis process (Silva et al., 2013). Some situations may occur in which no productivity differentials existed at reduced spacing, as the influence of this factor depends on the characteristics of different cultivars (Lima et al., 2012).

The reduction in spacing did not directly influence the ASR control level, therefore, it was observed that the cultivars had features that allowed the adequate deposition and distribution of the fungicides throughout the plant. Due to the characteristics of the soybean, the approximation of the cultivation rows may negatively impact the air circulation and increase the relative humidity, favoring the incidence of diseases (Sutton et al., 1984). These diseases appear particularly in the lower third of the plants, due to the lower thermal amplitude, as well as the dew evaporation delay, ideal for $P$. pachyrhizi spore germination and infection. Consequently, it is observed that the reduction in row spacing may provide favorable conditions for ASR progression, compromising the control of the disease, due to difficulties in the distribution of the fungicide throughout the plant and impacting in the grain yield's value (Holtz et al., 2014; Madalosso et al., 2010).

\section{CONCLUSIONS}

The Vortex $^{\circledR}$ and Dropleg ${ }^{\circledR}$ spray bar support mechanisms do not effectively contribute to maximizing Asian soybean rust control and grain yield, regardless of the cultivar and row spacing. The reduction of row spacing did not influence the level of control of Asian soybean rust, as the highest grain yield was obtained with the smallest spacing. The cultivar with genetic resistance to Asian rust showed lower levels of this disease, thus, greater control against the use of fungicides.

\section{REFERENCES}

Almeida R, Forcelini CA, Garcés-Fiallos, FR (2017) Chemical control of foliar diseases in soybean depends on cultivar and sowing date. Bioscience Journal 33(5):1188-1196.

Araújo MM, Vello NA (2010) Characterization of soybean genotypes for Asian soybean rust reaction. Crop Breeding and Applied Biotechnology 10(3):197-203.

ASABE - American Society of Agricultural and Biological Engineers (2009). S572.1: Spray nozzle classification by droplet spectra. St. Joseph, MI: ASABE.

Baesso MM, Rodrigues Junior FA, Magno Junior RG, Teixeira MM, Modolo AJ (2014) Population and spectrum of droplets produced during electrostatic spraying and hydraulic spraying using air assistance. Engenharia na Agricultura 22(5):408-412.

Bonadio JAB, Arcuri Neto J, Costa NV, Ramella JRP (2015) Tecnologia de aplicação de defensivos agrícolas: inovações. In: Kuhn OJ et al. (orgs). Ciências agrárias: tecnologias e perspectivas. Marechal Cândido Rondon: Universidade Estadual do Oeste do Paraná, 360p. 
Christovam RS, Raetano, CG, Aguiar Junior HO, Dal-Pogetto MHFA, Prado EP, Gimenes Junior M, Kunz VL (2010) Assistência de ar em barra de pulverização no controle da ferrugem asiática da soja. Bragantia 69(1):231-238.

Cunha JPRC, Marques RS, Alves GS (2016) Deposição da calda na cultura da soja em função de diferentes pressões de trabalho e pontas de pulverização. Ceres 63(6):761-768.

Cunha JPAR, Juliatti FC, Reis EF (2014) Tecnologia de aplicação de fungicidas no controle da ferrugem asiática da soja: resultados de oito anos de estudos em Minas Gerais e Goiás. Bioscience Journal 30(4):950-957.

Cunha JPAR, Farnese AC, Olivet JJ, Villalba, J (2011) Deposição de calda pulverizada na cultura da soja promovida pela aplicação aérea e terrestre. Engenharia Agrícola 31(2):343-351.

Dalla Lana F, Ziegelmann PK, Maia AHN, Godoy CV, Del Ponte EM (2015) Meta-Analysis of the Relationship Between Crop Yield and Soybean Rust Severity. Phytopathology 105(3):307-315.

Danelli ALD, Reis EM, Boaretto C (2015) Critical-point model to estimate yield loss caused by Asian soybean rust. Summa Phytopathologica 41(4):262-269.

Debortoli MP, Tormen NR, Balardin RS, Fávera DD, Stefanello MT, Pinto FF, Uebel JD (2012) Efeito dos espectros de gota associados a diferentes arquiteturas de cultivares de soja no controle da ferrugem. Pesquisa Agropecuária Brasileira 47(7):920-927.

Fehr WR, Caviness CE, Burmood DT, Pennington JS (1971) Stage of development descriptions for soybeans, Glycine max (L.) Merrill. Crop Science 11:929-931.

França JAL, Cunha JPAR, Antuniassi UR (2018) Spectrum and velocity of droplets of spray nozzles with and without air induction. Engenharia Agrícola 38(2):232-237.

Godoy CV, Seixas CD, Soares RM, Guimarães FCM, Meyer MC, Costamilan LM (2016) Asian soybean rust in Brazil: past, present, and future. Pesquisa Agropecuária Brasileira 51(5):407-421.

Graziano CEPL, Alves KA, Gandolfo MA, Dario G, Oliveira RB (2017) Spraying quality of crop protection products using two droplet spectra in three periods of the day. Engenharia Agrícola 37(6):1183-1189.

Holtz V, Couto RF, Oliveira DG, Reis EF (2014) Deposição de calda de pulverização e produtividade da soja cultivada em diferentes arranjos espaciais. Ciência Rural 44(8):1371-1376.

Langenbach C, Campe R, Beyer SF, Mueller AN, Conrath U (2016) Fighting Asian Soybean Rust. Plant Science 7(979):1-14.

Lima SF, Alvarez RCF, Theodoro GF, Bavaresco M, Silva KS (2012) Efeito da semeadura em linhas cruzadas sobre a produtividade de grãos e severidade da ferrugem asiática da soja. Bioscience Journal 28(6):954-962.

Madalosso MG, Domingues LS, Debortoli MP, Balardin RS (2010) Cultivares, espaçamento entrelinhas e programas de aplicação de fungicidas no controle de Phakopsora pachyrhizi Sidow em soja. Ciência Rural 40(11):2256-2261.

Madureira RP, Raetano CG, Cavalieri JD (2015) Interação pontas-adjuvantes na estimativa do risco potencial de deriva de pulverizações. Engenharia Agrícola e Ambiental

19(2):180-185.
Melo CLP, Roese AD, Goulart ACP (2015) Tolerância de genótipos de soja à ferrugem-asiática. Ciência Rural 45(8):1353-1360.

Moura B, Deuner CC, Visintin G, Boller W (2017) Use of a canopy opener in fungicide applications to improve asian soybean rust control. Transactions of the ASABE 60(6):1819-1825

Nascimento JM, Gavassoni WL, Souza CMA, Bacchi LMA, Serra AP, Zaccaron ML (2013) Pontas de pulverização e horários de aplicação no controle químico de ferrugem asiática da soja. Semina: Ciências Agrárias 34(5):2037-2048.

Prado EP, Raetano CG, Dal Pogetto MHF, Costa SAI, Christovam RS (2015) Taxa de aplicação e uso de surfactante siliconado na deposição da pulverização e controle da ferrugem da soja. Engenharia Agrícola 35(3):514-527

Oliveira GM, Canteri MG, Saab OJGA (2016) Meta-analysis of scientific studies related to pesticide application techniques-air assistance and adjuvant addition. Ciência Rural 46(12):2122-2128.

Prado EP, Raetano CG, Aguiar Júnior HO, Dal Pogetto MHFA, Christovam RS, Gimenes MJ, Araújo D (2010) Velocidade do ar em barra de pulverização na deposição da calda fungicida, severidade da ferrugem asiática e produtividade da soja. Summa Phytopathologica 36(1):45-50.

Reis EM, Reis AC, Carmona M, Danelli ALD (2012) Ferrugem Asiática. In: Reis EM, Casa RT (orgs). Doenças da soja. Passo Fundo, Berthier, p69-101

Reis EM, Reis AC, Carmona MA (2010) Manual de fungicidas: guia para o controle químico de doenças de plantas. Passo Fundo, UPF, 6 ed. 153 p.

Roten RL, Hewitt AJ, Ledebuhr M, Thistle H, Connell RJ, Wolf TM, Sankar S, Woodward SJR (2013) Evaluation of spray deposition in potatoes using various spray delivery systems. New Zealand Plant Protection 66:317-323.

Rüegg J, Total R (2013) Dropleg-Application Technique for better targeted sprays in row crops Introduction and Hints for Growers and Advisers. Agroscope, Waedenswill, 27 p.

Silva BM, Ruas RAA, Sichocki D, Dezordi LR, Caixeta LF (2014) Deposição da calda de pulverização aplicada com pontas de jato plano em diferentes partes da planta de soja (Glycine max) e milho (Zea mays). Engenharia na agricultura 22(1):17-24.

Silva WB, Petter FA, Lima LB, Andrade FR (2013)

Desenvolvimento inicial de Urochloa ruziziensis e desempenho agronômico da soja em diferentes arranjos espaciais no cerrado Mato-Grossense. Bragantia 72(2):146-153.

Sutton JC, Gillespie TJ, Hildebrand PD (1984) Monitoring weather factors in relation to plant disease. Plant disease 68(1):78-84

Tormen NR, Silva FDL, Debortoli MP, Uebel JD, Fávera DD, Balardin RS (2012) Deposição de gotas no dossel e controle químico de Phakopsora pachyrhizi na soja. Engenharia Agrícola e Ambiental 16(7):802-808.

Weber NC, Santos EM, Russini A, Silva FF (2017) Deposição de calda ao longo do dossel na cultura da soja utilizando pulverizador equipado com controlador de fluxo. Engenharia na Agricultura 25(5):459-468. 